\title{
PENGELOMPOKAN KEJADIAN GEMPA BUMI MENGGUNAKAN FUZZY C-MEANS CLUSTERING
}

\author{
Ryan Rifqi Arista ${ }^{1}$, Rosa Andrie Asmara ${ }^{2}$, Dwi Puspitasari ${ }^{3}$ \\ Program Studi Teknik Informatika, Jurusan Teknologi Informasi, Politeknik Negeri Malang. \\ ryanrfq5@gmail.com¹, rosa_andrie@polinema.ac.id², dwi.puspitasari@polinema.ac.id ${ }^{3}$
}

\begin{abstract}
The region of Indonesia has a high degree of earthquake vulnerability when compared with other countries. This is because the position of Indonesia is at the meeting of three large tectonic plates of the Eurasian plate, the Indo-Australian plate, and the Pacific plate. This high earthquake vulnerability is evidenced by significant earthquake events data from 2005 to 2009, recorded in the period of 26 significant earthquakes with magnitude ranges between 4.8 to 8.6 on the Richter scale. The earthquake incident also caused impacts such as casualties, injuries, damage to homes and the destruction of houses. Earthquake event clustering system is a system that serves to classify earthquake events based on two main parameters, namely earthquake strength parameters and earthquake impact parameters. Both parameters are grouped separately, so the grouping process produces two kinds of groupings. Stages of this system start from preprocessing data to eliminate noise, then take clustering parameters from user in the form of cluster number, minimum error value, and maximum iteration limit. Grouping is done using fuzzy c-means method. The grouping results are then displayed in table form and in the form of coordinate points in Google Maps. This earthquake event clustering has been tested by comparing the result of grouping the system with manual grouping results. Testing is done by inputting the number of different maximum iterations. Based on the test results obtained that the greater the maximum iteration value will affect the accuracy of the grouping.
\end{abstract}

Kata Kunci: Data Mining, Clustering, Fuzzy C-Means, Badan Meteorologi Klimatologi dan Geofisika

\section{Pendahuluan}

Berdasarkan peta seismik dunia, diketahui bahwa wilayah Indonesia memiliki tingkat kerawanan gempa yang cukup tinggi jika dibandingkan dengan negara-negara lainnya. Hal tersebut disebabkan posisi Indonesia berada pada pertemuan tiga lempeng besar yang terus-menerus bergerak (Naryanto, H. \& Wisyanto. 2005). Ketiga lempeng tektonik besar tersebut yaitu Lempeng Tektonik Eurasia, Lempeng Tektonik Indonesia Indo-Australia, dan Lempeng Tektonik Pasifik. Selain lempeng-lempeng tersebut, masih ada lempeng-lempeng tektonik kecil lainnya yaitu Filipina, Laut Maluku, Halmahera, dan Sangihe. Pergerakan lempeng-lempeng tektonik tersebut merupakan penyebab terjadinya gempa bumi tektonik di Indonesia dan akibatnya Indonesia merupakan salah satu negara yang mempunyai tingkat kegempaan yang tinggi di dunia (Santoso, E 2005).

Pada tahun 2007 tercatat 1.177 gempa dengan magnitudo lebih besar dari 4 Skala Richter (SR) dengan rincian 613 kejadian diatas 5,0 SR, 57 kejadian diatas 6,0 SR, dan 5 kali kejadian di atas 7,0 SR. Berdasarkan data tersebut, 411 kejadian diantaranya merupakan gempa yang signifikan yang dapat dirasakan manusia dan termasuk diantaranya gempa yang bersifat merusak (Setiawan, K. 2009).

Mengetahui fakta diatas, maka dapat dilakukan pengelompokan kejadian gempa bumi menggunakan parameter kekuatan gempa dan dampak akibat gempa. Kedua parameter utama tersebut nantinya dilakukan proses pengelompokan secara terpisah. Hasil pengelompokan ini tidak dapat menentukan tingkat keparahan suatu kejadian gempa, namun dari hasil pengelompokan kedua parameter tersebut dapat dicari keterkaitan antara kelompok parameter kekuatan gempa dan kelompok parameter dampak gempa.

Metode yang akan digunakan untuk penelitian ini adalah Fuzzy C-Means (FCM). Metode ini jika dibandingkan dengan metode K-Means lebih baik karena memiliki hasil pengelompokan yang lebih stabil karena inisialisasi matriks u dilakukan secara random dan konsep yang digunakan adalah derajat keanggotaan. Sedangkan pada metode K-Means inisialisasi matriks dilakukan dengan mengambil nilai salah satu record dari dataset yang dikelompokkan, sehingga nilai awal ini sangat berpengaruh dan jika diubah juga dapat mengubah hasil akhir pengelompokan. Algoritma FCM memberi kebebasan dalam hal jumlah cluster yang 
akan dibuat. Kelebihan lainnya adalah ia dapat melakukan clustering lebih dari satu variabel secara sekaligus[5]. Data-data beserta parameterparameternya dapat dikelompokkan dalam clustercluster sesuai dengan kecenderungannya. FCM juga memiliki tingkat akurasi yang tinggi dan waktu komputasi yang cepat.

\section{TINJAUAN PUSTAKA}

\subsection{Penelitian Terdahulu}

Penelitan Hepita Artatia (2015) yang berjudul "Pengelompokan Dampak Gempa Bumi dari Segi Kerusakan Fasilitas pada Provinsi yang Berpotensi Gempa di Indonesia Menggunakan K-MeansClustering" menunjukkan penerapan metode kmeans dalam pemetaan daerah terdampak gempa bumi berdasarkan tingkat kerusakan rumah, kerusakan jalan, dan kerusakan lahan.

Penelitian Indra Setiawan yang berjudul "Penerapan Metode Clustering untuk Memetakan Potensi Tanaman Kedelai di Jawa Tengah dengan Algoritma Fuzzy C-Means" menunjukkan pemetaan daerah penghasil tanaman kedelai terbesar dengan menggunakan algoritma fuzzy c-means. Data yang dianalisis adalah nama kabupaten/kota, luas panen, hasil panen per hektar, produksi per ton, dan tahun. Perhitungan dilakukan dengan fuzzy c-means, yang menghasilkan pengelompokan daerah-daerah yang menghasilkan kedelai.

Penelitian Emha Taufiq Luthfi (2007) yang berjudul "Fuzzy C-Means untuk Clustering Data (Studi Kasus Data Performance Mengajar Dosen)" menghitung performa mengajar dosen berdasarkan lima kriteria yaitu penguasaan materi, kemampuan menjawab pertanyaan, kemampuan memberi motivasi, kedisiplinan hadir, dan kemampuan membuat suasana kelas menyenangkan. Data dari kelima kriteria tersebut kemudian dihitung menggunakan fuzzy c-means, sehingga menghasilkan empat cluster nilai IPK dosen.

Penelitian Hanna dan Irhamah (2013) yang berjudul "Pengelompokan Kabupaten/Kota di Provinsi Jawa Timur Berdasarkan Indikator Pendidikan SMA/SMK/MA dengan Metode CMeans dan Fuzzy C-Means" menggunakan metode Fuzzy C-Means untuk mengelompokkan Kabupaten/Kota di Jawa Timur berdasarkan pendidikannya.

\subsection{Landasan Teori}

\subsubsection{Gempa Bumi}

Gempa bumi adalah getaran bumi yang dihasilkan oleh percepatan energi yang dilepaskan, energi ini menyebar ke segala arah dari pusat sumbernya. Gempa bumi di Indonesia seringkali dijumpai, mengingat Indonesia merupakan pertemuan tiga buah lempeng tektonik yang membentuk jalur-jalur gempa dan jalur vulkanik yang memberikan dampak besar terhadap distribusi penyebaran gempa di Indonesia. Gempa bumi yang perlu mendapatkan perhatian karena memiliki kemungkinan dampak kerusakan yang besar adalah gempa tektonik. Hal yang perlu diketahui adalah besarnya frekuensi yang terjadi, energi yang dibebaskan, dan luas pengaruhnya dalam kaitannya dengan pergerakan lempeng tektonik. Pusat-pusat gempa bumi tektonik berkaitan erat dengan tempattempat yang sering terjadi pergerakan pada kulit bumi yaitu di zona subduksi dan patahan.

\subsubsection{NOAA}

NOAA adalah lembaga pemerintahan Amerika Serikat yang memiliki tugas untuk mengamati perubahan iklim, cuaca, serta ekosistem laut dan pantai. NOAA memiliki cabang yang bernama NCEI (National Centers for Environmental Information) yang bertugas untuk menyimpan arsip tentang data lingkungan dan bumi yang dapat diakses oleh publik. NCEI sendiri terbagi menjadi beberapa bagian, salah satunya adalah NGDC (National Geophysical Data Center) yang menyimpan datadata kejadian geofisikal, salah satunya adalah kejadian gempa bumi yang dibahas pada penelitian ini.

\subsubsection{Data Mining}

Data mining adalah suatu istilah yang digunakan untuk menemukan pengetahuan yang tersembunyi di dalam database. Data mining merupakan proses semi otomatik yang menggunakan teknik statistik, matematika, kecerdasan buatan, dan machine learning untuk mengekstraksi dan mengidentifikasi informasi pengetahuan potensial dan berguna yang bermanfaat yang tersimpan di dalam database besar.

Secara sederhana data mining adalah penambangan atau penemuan informasi baru dengan mencari pola atau aturan tertentu dari sejumlah data yang sangat besar. Data mining juga disebut sebagai serangkaian proses untuk menggali nilai tambah berupa pengetahuan yang selama ini tidak diketahui secara manual dari suatu kumpulan data. Data mining, sering juga disebut sebagai Knowledge Discovery in Database (KDD). KDD adalah kegiatan yang meliputi pengumpulan, pemakaian data, 
historis untuk menemukan keteraturan, pola atau hubungan dalam set data berukuran besar.

\subsubsection{Clustering}

Clustering adalah salah satu alat bantu pada data mining yang bertujuan mengelompokkan obyek-obyek ke dalam cluster-cluster. Cluster adalah sekelompok atau sekumpulan obyek-obyek data yang similar satu sama lain dalam cluster yang sama dan dissimilar terhadap obyek-obyek yang berbeda cluster. Obyek akan dikelompokkan ke dalam satu atau lebih cluster sehingga obyek-obyek yang berada dalam satu cluster akan mempunyai kesamaan yang tinggi antara satu dengan lainnya. Obyek-obyek dikelompokkan berdasarkan prinsip memaksimalkan kesamaan obyek pada cluster yang sama dan memaksimalkan ketidaksamaan pada cluster yang berbeda. Kesamaan obyek biasanya diperoleh dari nilai-nilai atribut yang menjelaskan obyek data, sedangkan obyek-obyek data biasanya direpresentasikan sebagai sebuah titik dalam ruang multidimensi.

Tujuan utama dari metode clustering adalah pengelompokan sejumlah data/obyek ke dalam cluster (group) sehingga dalam setiap cluster akan berisi data yang semirip mungkin. Dalam clustering metode ini berusaha untuk menempatkan obyek yang mirip (jaraknya dekat) dalam satu klaster dan membuat jarak antar klaster sejauh mungkin. Ini berarti obyek dalam satu cluster sangat mirip satu sama lain dan berbeda dengan obyek dalam clustercluster yang lain. Dalam metode ini tidak diketahui sebelumnya berapa jumlah cluster dan bagaimana pengelompokannya.

\subsubsection{Fuzzy C-Means}

Fuzzy C-means Clustering (FCM) dikenal juga sebagai Fuzzy ISODATA. FCM menggunakan model pengelompokan fuzzy sehingga data dapat menjadi anggota dari semua kelas atau cluster terbentuk dengan derajat atau tingkat keanggotaan yang berbeda antara 0 hingga 1 . Tingkat keberadaan data dalam suatu kelas atau cluster ditentukan oleh derajat keanggotaannya. Teknik ini pertama kali diperkenalkan oleh Jim Bezdek pada tahun 1981.

Konsep dasar FCM, pertama kali adalah menentukan pusat cluster yang akan menandai lokasi rata-rata untuk tiap-tiap cluster. Pada kondisi awal, pusat cluster ini masih belum akurat. Tiap-tiap data memiliki derajat keanggotaan untuk tiap-tiap cluster. Dengan cara memperbaiki pusat cluster dan nilai keanggotaan tiap-tiap data secara berulang, maka dapat dilihat bahwa pusat cluster akan menujui lokasi yang tepat. Perulangan ini didasarkan pada minimasi fungsi obyektif yang menggambarkan jarak dari titik data yang diberikan ke pusat cluster yang terbobot oleh derajat keanggotaan titik data tersebut.

Output dari Fuzzy C-Means bukan merupakan fuzzy inference system, namun merupakan deretan pusat cluster dan beberapa deret keanggotaan untuk tiap-tiap titik data. Informasi ini dapat digunakan untuk membangun suatu fuzzy inference system. FCM menggunakan model pengelompokan fuzzy sehingga data dapat menjadi anggota dari semua kelas atau cluster tersebut dengan derajat keanggotaan yang berbeda antara 0 hingga 1 .

\section{METODOLOGI PENELITIAN}

\subsection{Analisa Data}

Pada tahap ini akan dilakukan analisis data mulai dari memasukan data sampai menjadi hasil yang berupa informasi, yaitu:

\section{a) Preprocessing}

Pada tahap ini struktur basis data akan dipersiapkan sehingga mempermudah proses mining. Proses preprocessing ini mencakup tiga hal utama yaitu:

\section{1) Seleksi Data}

Memilih data yang akan digunakan dalam proses data mining. Dalam penelitian ini dipilih 6 variabel yaitu kedalaman gempa dan magnitudo gempa, jumlah korban meninggal, jumlah korban luka-luka, jumlah rumah rusak dan jumlah rumah hancur.

\section{2) Cleaning}

Proses cleaning data perlu dilakukan agar data bersih dari duplikasi data, data yang tidak konsisten, atau kesalahan cetak. Sehingga data yang telah melewati proses ini siap untuk di proses di data mining. Pada penelitian ini proses pembersihan data dilakukan pada tabulasi dan spasi yang berlebihan, serta menghapus baris pertama file yang tidak digunakan oleh sistem.

3) Integrasi data

Setelah melakukan pembersihan data yang menyeluruh, maka akan dilakukan tahapan selanjutnya yaitu integrasi data, karena data lebih dari satu tabel maka dilakukan tahap penggabungan data dari berbagai tabel. Kemudian data padi diberi kode agar tidak ada data yang memiliki nama yang sama. Pada penelitian ini tidak dilakukan proses integrasi data karena data berasal dari satu tabel saja.

\section{b) Data Mining}

Proses data mining yang dilakukan pada penelitian ini adalah menerapkan teknik clustering 
dengan algoritma Fuzzy C-Means untuk mendapatkan karakteristik dari data. Cluster yang digunakan pada penelitian ini sebanyak tiga klaster.

Konsep dasar FCM (Fuzzy C-Means) pertama kali adalah menentukan pusat cluster yang akan menandai lokasi rata-rata untuk tiap cluster. Pada kondisi awal, pusat cluster ini masih belum akurat. Tiap-tiap titik data memiliki derajat keanggotan untuk tiap-tiap cluster. Dengan cara memperbaiki pusat cluster dan derajat keanggotaan tiap-tiap titik data secara berulang, maka akan dapat dilihat bahwa pusat cluster akan bergerak menuju lokasi yang tepat. Perulangan ini didasarkan pada derajat keanggotaan yang menggambarkan jarak dari titik data yang diberikan ke pusat cluster yang terbobot oleh derajat keanggotaan titik data tersebut.

Pada perhitungan menggunakan FCM dengan menggunakan data yang sama tetapi diolah dengan jumlah cluster yang berbeda, maka hasil pengelompokannya akan sedikit berbeda, karena data tidak diolah dengan satu variabel saja tetapi dengan semua variabel. Perbedaan hasil pengelompokan itu dikarenakan data pada kelompok tertentu kemungkinan akan berpindah pada kelompok lain jika diolah dengan jumlah cluster yang berbeda, ini menunjukkan bahwa sistem aplikasi sudah berjalan dengan benar.

Output dari pengelompokan ini adalah clustercluster dari parameter kekuatan gempa dan parameter dampak gempa:

1) Input Data

input data yang akan dicluster yaitu data kejadian gempa (X) berupa matrik berukuran $\mathrm{n} \times \mathrm{m}(\mathrm{n}=$ jumlah data, $\mathrm{m}=$ atribut setiap data). $\mathrm{Xij}=$ data ke- $i(i=1,2, \ldots, n)$, atribut ke- $j(j=1,2, \ldots, m)$.

2) Batasan
a) Jumlah cluster (c) $=3$
b) Pangkat $(\mathrm{w})=$
c) Maksimum iterasi (MaxIter) $=30$
d) Fungsi obyektif awal $\left(\mathrm{P}_{0}\right)=0$
e) Iterasi awal ( $\mathrm{t})=1$

3) Membangkitkan bilangan random $\mu \mathrm{ik}, \mathrm{i}=1$, $2, \ldots, \mathrm{n} ; \mathrm{k}=1,2, \ldots, \mathrm{c} ;$ sebagai elemen-elemen matrik partisi awal $\mathrm{U}$, dengan jumlah setiap nilai elemen kolom dalam satu baris adalah 1 (satu)

$$
\sum_{i=1}^{c} \mu_{c i}=1
$$

4) Menghitung pusat cluster ke- $\mathrm{k}:$ Vkj dengan $\mathrm{k}=$ $1,2, \ldots, c ;$ dan $\mathrm{j}=1,2, \ldots, \mathrm{m}$.

$$
V_{k j}=\frac{\sum_{i=1}^{n}\left(\left(u_{i k}\right)^{w}\right) X_{i j}}{\sum_{i=1}^{n}\left(u_{i k}\right)^{w}}
$$

5) Menghitung fungsi obyektif pada iterasi ke-t, Pt:

$$
\begin{aligned}
P_{t}=\sum_{i=1}^{n} \sum_{k=1}^{c}( & \left(\sum _ { j = 1 } ^ { m } \left(X_{i j}\right.\right. \\
& \left.\left.\left.-V_{k j}\right)^{2}\right]\left(\mu_{i k}\right)^{w}\right)
\end{aligned}
$$

6) Menghitung perubahan matrik partisi:

$$
\mu_{i k}=\frac{\left[\sum_{j=1}^{m}\left(X_{i j}-V_{k j}\right)^{2}\right]^{\frac{-1}{w-1}}}{\sum_{k=1}^{c}\left[\sum_{j=1}^{m}\left(X_{i j}-V_{k j}\right)^{2}\right]^{\frac{-1}{w-1}}}
$$

dengan $\mathrm{i}=1,2, \ldots, \mathrm{n}$; dan $\mathrm{k}=1,2, \ldots, \mathrm{c}$.

7) Mengecek kondisi berhenti:

1. Jika $(|\mathrm{Pt}-\mathrm{Pt}-1|<\xi)$ atau ( $\mathrm{t}>$ MakIter) maka berhenti;

2. Jika tidak, $\mathrm{t}=\mathrm{t}+1$, ulangi langkah ke-d (menghitung Vkj).

\section{c) Postprocessing}

Postprocessing bertujuan untuk membantu pengguna dalam memahami informasi. Postprocessing dalam penelitian ini berupa output dalam bentuk tabel dan dalam koordinat Google Maps.

\subsection{Implementasi}

\subsubsection{Implementasi Basis Data}

Basis data yang dibuat diberi nama db_clusteringgempa. Basis data tersebut berisi tiga tabel yaitu 'tb_datagempa', 'tb_hasiltraining' dan 'tb_minmax'.

Tabel 'tb_datagempa' yang menampung data hasil upload dari user. Tabel ini berisi field yang digunakan saat proses pengelompokan.

Tabel 3.1. Struktur tabel`tb_datagempa`

\begin{tabular}{|c|c|}
\hline Nama Kolom & $\begin{array}{c}\text { Tipe } \\
\text { Data }\end{array}$ \\
\hline ID_DATAGEMPA & $\operatorname{int}(4)$ \\
\hline TANGGAL & date \\
\hline FOCAL_DEPTH & $\operatorname{int}(4)$ \\
\hline EQ_PRIMARY & double \\
\hline LOCATION_NAME & $\begin{array}{c}\text { varchar( } \\
50)\end{array}$ \\
\hline LATITUDE & double \\
\hline LONGITUDE & double \\
\hline
\end{tabular}


Jurnal Teknologi Informatika dan Terapan Vol. 04, No 02, Juli - Desember 2017 ISSN: 235-838X

\begin{tabular}{|c|c|}
\hline Nama Kolom & $\begin{array}{c}\text { Tipe } \\
\text { Data }\end{array}$ \\
\hline TOTAL_DEATHS & $\operatorname{int}(6)$ \\
\hline TOTAL MISSING & $\operatorname{int}(2)$ \\
\hline TOTAL_INJURIES & $\operatorname{int}(5)$ \\
\hline $\begin{array}{c}\text { TOTAL_HOUSES_DESTRO } \\
\text { YED }\end{array}$ & $\operatorname{int}(6)$ \\
\hline $\begin{array}{c}\text { TOTAL_HOUSES_DAMAG } \\
\text { ED }\end{array}$ & $\operatorname{int}(6)$ \\
\hline
\end{tabular}

Tabel 'tb_hasiltraining' yang menampung data hasil pengelompokan fuzzy c-means. Field 'ID_DATAGEMPA' merupakan foreign key yang referensinya di tabel 'tb_datagempa'. Field 'cluster_kekuatan' menyimpan hasil pengelompokan dari parameter kekuatan, sedangkan field 'cluster_dampak' menyimpan hasil pengelompokan dari parameter dampak gempa.

Tabel 3.2. Struktur tabel 'tb_hasiltraining`

\begin{tabular}{|c|c|}
\hline Nama Kolom & Tipe Data \\
\hline ID_DATAGEMPA & $\operatorname{int}(4)$ \\
\hline cluster_kekuatan & $\operatorname{int}(2)$ \\
\hline cluster_dampak & $\operatorname{int}(2)$ \\
\hline
\end{tabular}

Tabel 'tb_minmax' digunakan untuk menyimpan nilai maksimum dan minimum dari suatu parameter untuk sebuah cluster, misalnya magnitudo maksimum dan minimum dari cluster 1 untuk parameter kekuatan.

Tabel 5.1 Struktur tabel `tb_minmax`

\begin{tabular}{|c|c|}
\hline Nama Kolom & $\begin{array}{c}\text { Tipe } \\
\text { Data }\end{array}$ \\
\hline param & $\begin{array}{c}\text { varcha } \\
\text { (20) }\end{array}$ \\
\hline cluster & $\operatorname{int}(2)$ \\
\hline jml_record & $\operatorname{int}(3)$ \\
\hline EQ_PRIMARY_MAX & $\operatorname{double}$ \\
\hline EQ_PRIMARY_MIN & $\operatorname{double}$ \\
\hline FOCAL_DEPTH_MAX & $\operatorname{int}(4)$ \\
\hline FOCAL_DEPTH_MAX & $\operatorname{int}(4)$ \\
\hline TOTAL_DEATHS_MAX & $\operatorname{int}(6)$ \\
\hline TOTAL_DEATHS_MIN & $\operatorname{int}(6)$ \\
\hline TOTAL_MISSING_MAX & $\operatorname{int}(2)$ \\
\hline TOTAL_MISSING_MIN & $\operatorname{int}(2)$ \\
\hline TOTAL_INJURIES_MAX & $\operatorname{int}(5)$ \\
\hline
\end{tabular}

\begin{tabular}{|c|c|}
\hline TOTAL_INJURIES_MIN & $\operatorname{int}(5)$ \\
\hline $\begin{array}{c}\text { TOTAL_DAMAGE_MILLIONS_D } \\
\text { OLLARS_MAX }\end{array}$ & $\operatorname{int}(8)$ \\
\hline $\begin{array}{c}\text { TOTAL_DAMAGE_MILLIONS_D } \\
\text { OLLARS_MIN }\end{array}$ & $\operatorname{int}(8)$ \\
\hline $\begin{array}{c}\text { TOTAL_HOUSES_DESTROYED_ } \\
\text { MAX }\end{array}$ & $\operatorname{int}(6)$ \\
\hline $\begin{array}{c}\text { TOTAL_HOUSES_DESTROYED_ } \\
\text { MIN }\end{array}$ & $\operatorname{int}(6)$ \\
\hline $\begin{array}{c}\text { TOTAL_HOUSES_DAMAGED_M } \\
\text { AX }\end{array}$ & $\operatorname{int}(6)$ \\
\hline $\begin{array}{c}\text { TOTAL_HOUSES_DAMAGED_MI } \\
\text { N }\end{array}$ & $\operatorname{int}(6)$ \\
\hline
\end{tabular}

\subsubsection{Implementasi Antarmuka}

a) Implementasi Antarmuka Halaman Home

Halaman Home adalah halaman awal yang terbuka ketika user mengakses website. Halaman ini berisi informasi singkat mengenai sistem yang dibuat.

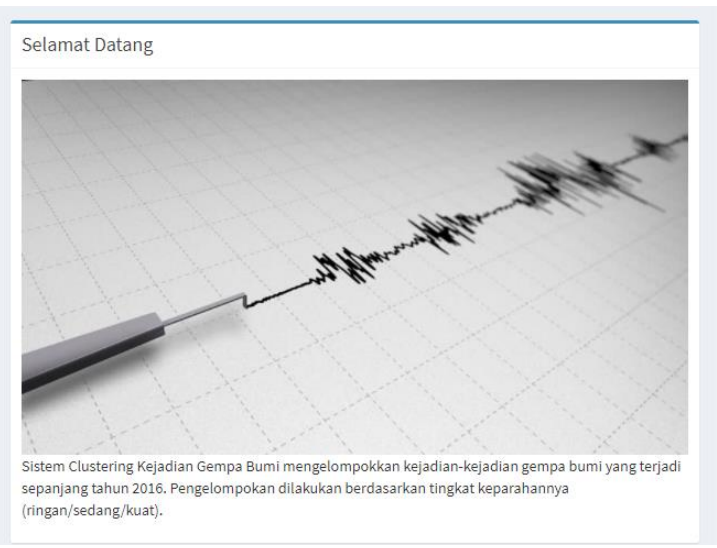

Gambar 3.1. Antarmuka Home

b) Implementasi Antarmuka Halaman Proses Fuzzy C-Means

Pada halaman Training Data ini user dapat melakukan upload dataset melalui form yang telah disediakan, serta terdapat tabel yang berfungsi untuk menampilkan data dari file yang telah diupload. User juga melakukan input parameter pengelompokan fuzzy c-means melalui halaman ini. 


\section{Pengelompokan Kejadian Gempa Bumi Menggunakan Fuzzy C-Means Clustering}

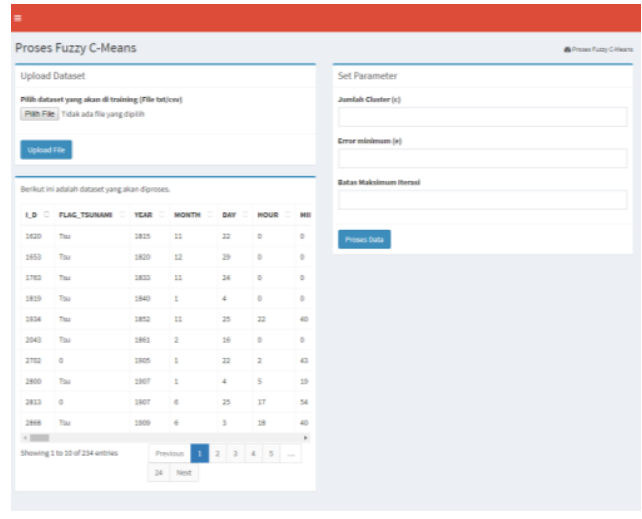

Gambar 3.2. Antarmuka Proses Fuzzy C-Means c) Implementasi Antarmuka Halaman Hasil Pengelompokan

Halaman hasil pengelompokan adalah halaman untuk menampilkan hasil perhitungan fuzzy c-means. Hasil pengelompokan ditampilkan dalam bentuk tabel dan dalam bentuk koordinat peta Google Maps. Bentuk peta ini dibagi menjadi tiga, peta yang pertama menampilkan koordinat gempa serta cluster yang dimiliki oleh koordinat tersebut untuk kedua parameter. Bentuk peta kedua menampilkan data gempa spesifik untuk parameter kekuatan. Tiap koordinatnya dapat memiliki warna yang berbedabeda tergantung cluster yang dimiliki oleh koordinat tersebut. Bentuk peta ketiga hampir sama dengan bentuk yang kedua, hanya saja data yang ditampilkan spesifik untuk parameter dampak saja.

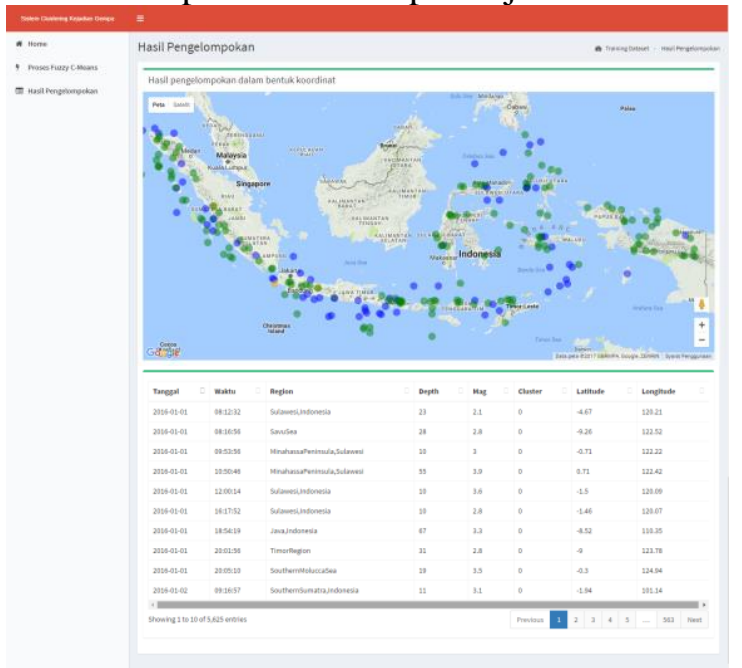

Gambar 3.3. Antarmuka Rekapitulasi

\subsection{Pengujian}

Untuk memastikan apakah perhitungan dengan metode fuzzy c-means sudah benar dilakukan uji coba perhitungan secara manual meggunakan MS. Excel. Selain itu pengujian juga dilakukan dengan membandingkan hasil perhitungan antara parameter kekuatan gempa dan parameter dampak gempa. Pengujian dilakukan untuk menghindari kesalahan dari sistem yang dibuat. Apabila terjadi kesalahan, maka sistem akan diperbaiki kembali sampai hasil proses sesuai dengan apa yang diharapkan.

\subsubsection{Pengujian Black Box}

Pengujian black box ini menguji performa sistem dalam hal ketepatan dalam proses clustering, yaitu ketepatan sistem dalam melakukan pengecekan iterasi. Berikut ini adalah hasil dari pengujian black box terhadap sistem, dengan jumlah cluster sebanyak 3 dan nilai error minimum adalah 0,01 .

\begin{tabular}{|c|c|c|}
\hline $\begin{array}{l}\text { Itera } \\
\text { si ke }\end{array}$ & $\begin{array}{rr}\begin{array}{r}\text { Selisih } \\
\text { (kekuatan) }\end{array} & \text { FO }\end{array}$ & $\begin{array}{cc}\begin{array}{c}\text { Selisih } \\
\text { (dampak) }\end{array} & \text { FO } \\
\end{array}$ \\
\hline 1 & 591017,636544 & $4 \quad 44721575607$ \\
\hline 2 & 10848,7555858 & $6 \quad 136269840,10$ \\
\hline 3 & 62082,8158558 & $\begin{array}{ll}7 & 5788701551,9\end{array}$ \\
\hline 4 & 119563,276615 & $16^{36309482603,}$ \\
\hline 5 & 241229,644875 & $\begin{array}{l}60427513667, \\
8\end{array}$ \\
\hline 16 & 97208,054432707 & $13^{6207322812,0}$ \\
\hline 17 & 57750,177414415 & $64 \quad 2029881036,5$ \\
\hline 18 & 36431,744450458 & $54 \quad 1009603257,7$ \\
\hline 19 & 24426,365132004 & $76^{584711708,03}$ \\
\hline 20 & 17232,350037528 & 41354058046,70 \\
\hline 31 & 993,03202192485 & $48^{2086243,6125}$ \\
\hline 32 & 779,23883805051 & $01 \quad 1317991,7666$ \\
\hline 33 & 611,65983665548 & $4^{832809,21191}$ \\
\hline 34 & 480,22940542456 & 79526308,15966 \\
\hline 35 & 377,10581168439 & $25^{332643,85156}$ \\
\hline 36 & 296,1664244337 & $85 \quad 210257,46630$ \\
\hline 37 & 232,62336159684 & $02 \quad 132906,73999$ \\
\hline 38 & 182,7282485608 & $28^{84015,562988}$ \\
\hline 39 & 143,5440528756 & $42 \quad 53111,063232$ \\
\hline 50 & 10,108949913643 & $75 \quad 342,40917968$ \\
\hline
\end{tabular}




\begin{tabular}{|c|c|c|}
\hline $\begin{array}{l}\text { Itera } \\
\text { si ke }\end{array}$ & $\begin{aligned} \text { Selisih } & \text { FO } \\
\text { (kekuatan) } & \end{aligned}$ & $\begin{array}{l}\text { Selisih } \\
\text { (dampak) }\end{array}$ \\
\hline 51 & 7,9428842226043 & $\begin{array}{ll} & 216,47460937\end{array}$ \\
\hline 52 & 6,24096249789 & $56^{136,85375976}$ \\
\hline 53 & 4,9037218010053 & $25^{86,521972656}$ \\
\hline 54 & 3,8530157050118 & $625^{54,695556640}$ \\
\hline 55 & 3,0274452902377 & $25^{34,580566406}$ \\
\hline 66 & 0.2133647305890 & $25^{0,2189941406}$ \\
\hline 67 & 0.1676486488431 & $75^{0,1442871093}$ \\
\hline 68 & $\begin{array}{ll} & 0.1317278146743 \\
8 & \end{array}$ & $25^{0,0891113281}$ \\
\hline 69 & $\begin{array}{ll} & 0.1035034805536 \\
3 & \\
\end{array}$ & $75^{0,0554199218}$ \\
\hline 70 & $0_{07} \quad 0.0813265973702$ & 0,033203125 \\
\hline 78 & $35^{0.0118155116215}$ & \\
\hline 79 & $\begin{array}{l}0.0092839077115 \\
059\end{array}$ & \\
\hline
\end{tabular}

ini dilakukan agar nilai nilai yang muncul tidak acak, sehingga hasil perhitungan sistem dapat dibandingkan dengan hasil perhitungan pada excel. a. Pengujian metode fuzzy c-means pada sistem

\begin{tabular}{|l|l|l|l|}
\hline No. & I_D & $\begin{array}{l}\text { cluster } \\
\text { kekuatan }\end{array}$ & $\begin{array}{l}\text { cluster } \\
\text { dampak }\end{array}$ \\
\hline 1 & 3010 & 0 & 2 \\
\hline 2 & 3046 & 0 & 2 \\
\hline 3 & 3047 & 0 & 2 \\
\hline 4 & 3064 & 1 & 2 \\
\hline 5 & 3572 & 1 & 2 \\
\hline 6 & 3600 & 1 & 1 \\
\hline 7 & 3745 & 0 & 2 \\
\hline 8 & 3749 & 1 & 1 \\
\hline 9 & 3955 & 1 & 2 \\
\hline 10 & 4178 & 1 & 0 \\
\hline 11 & 4240 & 1 & 2 \\
\hline 12 & 4307 & 1 & 2 \\
\hline 13 & 4334 & 0 & 1 \\
\hline 14 & 4394 & 1 & 1 \\
\hline 15 & 4396 & 0 & 2 \\
\hline
\end{tabular}

b. Pengujian Algoritma fuzzy c-means pada excel

\begin{tabular}{|l|l|l|l|}
\hline No. & I_D & $\begin{array}{l}\text { cluster } \\
\text { kekuatan }\end{array}$ & $\begin{array}{l}\text { cluster } \\
\text { dampak }\end{array}$ \\
\hline 1 & 3010 & 0 & 2 \\
\hline 2 & 3046 & 0 & 2 \\
\hline 3 & 3047 & 0 & 2 \\
\hline 4 & 3064 & 1 & 2 \\
\hline 5 & 3572 & 1 & 2 \\
\hline 6 & 3600 & 1 & 1 \\
\hline 7 & 3745 & 0 & 2 \\
\hline 8 & 3749 & 1 & 1 \\
\hline 9 & 3955 & 1 & 2 \\
\hline 10 & 4178 & 1 & 0 \\
\hline 11 & 4240 & 1 & 2 \\
\hline 12 & 4307 & 1 & 2 \\
\hline 13 & 4334 & 0 & 1 \\
\hline 14 & 4394 & 1 & 1 \\
\hline 15 & 4396 & 0 & 2 \\
\hline
\end{tabular}

Berdasarkan kedua tabel diatas dapat disimpulkan bahwa perhitungan clustering fuzzy cmeans antara sistem dengan excel menghasilkan nilai cluster yang sama untuk kedua parameter yang digunakan.

Dari hasil pengujian diatas dapat dilihat perbandingan hasil pengelompokan dari kedua parameter. Dari 15 data yang dikelompokkan, hanya tiga data yang masuk kedalam kelompok yang sama yaitu data dengan ID 3600, 3749, dan 4394. Sehingga dapat disimpulkan bahwa antara hasil 


\section{Pengelompokan Kejadian Gempa Bumi Menggunakan Fuzzy C-Means Clustering}

pengelompokan parameter kekuatan dengan parameter dampak kurang memiliki keterkaitan.

\section{DAFTAR PUSTAKA}

Naryanto, H S dan Wisyanto. 2005. Kajian dan Analisis Potensi Bencana Tsunami, Konfigurasi Pantai serta Mitigasi Bencana di Pantai Selatan Jawa Timur: Belajar dari Pengalaman Bencana Tsunami Banyuwangi Tahun 1994. Jurnal Alami. Vol 10 No 2 th. 2005. Jakarta.

Santoso, E.W. 2005. Penataan Ruang Kota Meulaboh Pasca Gempa Bumi dan Tsunami 26 Desember 2004. Usulan Rekomendasi. Jurnal Air, Lahan, Lingkungan, dan Mitigasi Bencana. P3TPSLK BBPT. Jakarta.

Setiawan, K. 2009. Waspada Bencana Bersama BMKG. Pustaka Cakra. Surakarta.

National Geophysical Data Center (NGDC). Diakses pada 13 Juli

https://www.ngdc.noaa.gov/hazard/earthqk.shtml.

Nurjanah, dkk. 2014. Implementasi Metode Fuzzy C-Means pada Sistem Clustering Data Varietas Padi. Kumpulan Jurnal Ilmu Komputer (KLIK). Universitas Lambung Mangkurat. Banjarbaru.

Hadi, HY. 2005. Pembagian Kelas Kuliah Mahasiswa Menggunakan Algoritma Pengklasteran Fuzzy. Universitas Diponegoro. Semarang.

Perdana, Sukma. 2016. Sumber Belajar Penunjang PLPG 2016: Hubungan Letak Astronomis, Geografis, Geologis dan Luas Wilayah dengan Sumberdaya di Indonesia.

Lutgens. 1982. Essentials of Geology. A Bell \& Howell Company. Ohio.

Hidayat, Nur dan Santoso, Eko Widi. 1997.Gempa Bumi dan Mekanismenya. Jurnal ALAMI: Jurnal Air, Lahan, Lingkungan, dan Mitigasi Bencana. Badan Pengkajian dan Penerapan Teknologi.
Supartoyo, dan Surono. 2008. Katalog Gempa Bumi Merusak di Indonesia tahun 1629 - 2007. Departemen Energi dan Sumber Daya Mineral, Badan Geologi Pusat Vulkanologi dan Mitigasi Bencana Geologi.

Winardi, A. 2006. Gempa Jogja, Indonesia \& Dunia. Gramedia. Jakarta.

Utami, Putri. 2014. Rancang Bangun Spasial Web Service Ancaman dan Resiko Bencana Alam (Studi Kasus: Wilayah Pemantauan Badan Nasional Penanggulangan Bencana).

Munir, Badrul. 2016. Analisis Hasil Pengamatan Hilal Badan Meteorologi Klimatologi dan Geofisika (BMKG) Pusat pada Tahun 2010M - 2015M.

Nugroho, Bunafit. 2004. Aplikasi Pemrograman Web Dinamis dengan PHP dan MySQL, Gava Media, Yogyakarta.

Peranginangin, Kasiman. 2006. Aplikasi Web dengan PHP dan MySQL. Penerbit Andi. Yogyakarta.

Turban, E. 2005. Decision Support System and Intelligent Systems. Penerbit Andi. Yogyakarta.

Davies, and Paul Beynon, 2004, Database Systems Third Edition, Palgrave Macmillan,_New York.

Pramudiono, I. 2007. Pengantar Data Mining: Menambang Permata Pengetahuan di Gunung Data.

Santosa, Budi, 2007, Data Mining Teknik Pemanfaatan Data untuk Keperluan Bisnis, Graha Ilmu, Yogyakarta.

Witten, I. H and Frank, E. 2005. Data Mining: Practical Machine Learning Tools and Techniques Second Edition. Morgan Kauffman: San Fransisco.

Luhfi, Emha Taufiq, 2007. Fuzzy C-Means untuk Clustering Data (Studi Kasus: Data Performance Mengajar Dosen).

Henjaya, R. 2010. Penerapan Algoritma K-Means pada Clustering Berita Berbahasa Indonesia. Universitas Indonesia. Jakarta. 